\title{
Effect of garlic and neem leaf powder supplementation on growth performance and carcass traits in broilers
}

\author{
Karan Rajendra Kharde ${ }^{1}$ and S. Soujanya²
}

1. Department of Poultry Science, College of Veterinary Science, Rajendranagar, Hyderabad, Telangana, India;

2. Department of Veterinary Pathology, College of Veterinary Science, Korutla, Karimnagar, Telangana, India. Corresponding author: S. Soujanya, e-mail: sonurv36@gmail.com, KRK: karankharde@gmail.com

Received: 25-06-2014, Revised: 31-08-2014, Accepted: 07-09-2014, Published online: 09-10-2014

doi: 10.14202/vetworld.2014.799-802. How to cite this article: Kharde KR, Soujanya S (2014) Effect of garlic and neem leaf powder supplementation on growth performance and carcass traits in broilers, Veterinary World 7(10): 799-802.

\begin{abstract}
Aim: Present experiment was designed to study the effect of supplementation of garlic and neem leaf powder (NLP) on growth performance and carcass yields in broilers.

Materials and Methods: A total of 210-day-old commercial male broiler chicks (Ven Cobb) were procured and randomly distributed in to seven treatments, each treatment had six replicates with five chicks per each replicate. Growth trial was conducted in a randomized block design comprising seven dietary treatments. T1 was served as control. T2 and T3 were fed with garlic powder (GP) 0.5, $1 \mathrm{~g} / \mathrm{kg}$ feed respectively. T4 and T5 were given with NLP 1, $2 \mathrm{~g} / \mathrm{kg}$ feed respectively. T6 was fed with $0.5 \mathrm{~g} / \mathrm{kg}$ GP and $1.0 \mathrm{~g} / \mathrm{kg}$ NLP. T7 was treated with $1.0 \mathrm{~g} / \mathrm{kg}$ GP and $2.0 \mathrm{~g} / \mathrm{kg}$ NLP. The body weight, feed consumption of individual bird was recorded at weekly interval and the body weight gain, feed conversion ratio (FCR) were calculated. At the end of 42 day, six birds from each dietary group were sacrificed to estimate the dressing yield and relative weights of giblet (liver, heart and gizzard).
\end{abstract}

Results: Supplementation of garlic and NLP alone and their combination significantly $(\mathrm{p}<0.05)$ improved the body weight gain and FCR whereas no significant ( $\mathrm{p}>0.05$ ) influence was observed in carcass parameters like dressing yield and giblet yield (heart, gizzard and liver) in all treatment groups.

Conclusions: Supplementation of GP alone showed poor performance, but when it was supplemented in combination with NLP there was improvement in performance parameters. These results indicated that the combination of GP and NLP can be used as alternates to coccidiostats for improving the performance. Such meat can be used as a designer meat as fetch higher price if marketed as branded item.

Keywords: body weight gain, carcass yield, feed conversion ratio, garlic, neem.

\section{Introduction}

Garlic contains at least 33 sulfur compounds, several enzymes, 17 amino acids and minerals such as selenium [1]. The sulphur compounds are responsible both for garlic's pungent odor and many of its medicinal effects like lowering cholesterol level [2]. There are also studies showing immunostimulatory function of garlic extracts [3]. Injury to the garlic bulb activates the enzyme alliinase, which metabolizes alliin to allicin. Allicin has antimicrobial effects against many viruses, bacteria, fungi and parasites [4].

Neem contains several active ingredient like, nimbidin, sodium nimbolide, gedunin, azadirachtin, mahmoodin, gallic acid, epicatechin and catechin, margalone, margolonone and isomargolonone, cyclic trisulphides, polysaccharides GIa, GIIa, GIIIa, GIb, NB-II peptidoglycon which all contribute to its beneficial medicinal properties [5]. Neem leaves and its constituents have been demonstrated to exhibit immunomodulatory, anti-inflammatory, antihyperglycemic, antiulcer, antimalarial, antifungal, antiviral, antioxidant, antimutagenic, anticarcinogenic properties [6].

Copyright: The authors. This article is an open access article licensed under the terms of the Creative Commons Attributin License (http:// creative commons.org/licenses/by/2.0) which permits unrestricted use, distribution and reproduction in any medium, provided the work is properly cited.
When neem as an herbal drug is incorporated in feed mixture, it promotes growth and improves feed efficiency and live body weight due to its antibacterial and hepatoprotective properties [7].

In the present study, the effect of supplementation of neem leaf powder (NLP) alone and in combination with garlic on body weight gain, feed conversion ratio (FCR) and carcass yield were evaluated in broiler birds.

\section{Materials and Methods}

\section{Ethical approval}

CPCSEA guidelines indicate that birds weighing up to $0.5 \mathrm{~kg}$ should be provided with a floor space of $929.03 \mathrm{~cm}^{2} /$ bird and the present experiment was conducted as per CPCSEA guidelines.

\section{Birds}

210-day-old commercial male broiler chicks (Ven Cobb) were procured and randomly distributed into seven treatments; each treatment had six replicates with five chicks per each replicate. The chicks were reared in battery brooders up to 6 weeks of age under standard management and vaccination schedule. The experiment was conducted at poultry experimental station, Department of Poultry Science, College of Veterinary Science, Rajendranagar, Hyderabad. 


\section{Housing and management}

Battery brooders, feed hoppers, waterer, nipple system pipes, nipples were cleaned thoroughly, disinfected and sterilized with a blow lamp prior to stocking chicks. Chicks were housed in battery brooder providing floor space of $929.03 \mathrm{~cm}^{2} /$ bird. During the experiment, light was provided continuously (24 h). Feed and water were offered ad libitum throughout the experimental period. Birds were immunized against Newcastle disease on $7^{\text {th }}$ (primary) and $28^{\text {th }}$ (booster) day of age with lasato vaccine and for infectious bursal disease (IBD) on $14^{\text {th }}$ day of age with IBD (intermediate-Georgia strain) vaccine.

The body weights of individual birds were recorded at weekly interval, and average body weight gain was calculated. Feed consumption of each replicate was recorded at weekly intervals, on the cumulative basis and feed consumption per bird per week was arrived at. The FCR was calculated as feed intake per unit body weight gain from 0 to 6 weeks of age at weekly intervals. At the end of experimental period (42 day) six birds from each dietary group (one bird from each replicate) were sacrificed to estimate dressing yield and relative weights of giblet (liver, heart and gizzard).

\section{Statistical analysis}

The data were analyzed using general linear model procedure of statistical package for social sciences $15^{\text {th }}$ version (Minitab Inc.) and comparison of means tested using Duncan's multiple range test (1955) and significance was considered at $\mathrm{p}<0.05$ [8].

\section{Results}

\section{Body weight gain}

Supplementation of garlic powder (GP) and NLP in broiler diets have significant $(\mathrm{p}<0.05)$ influence on body weight gains from $1^{\text {st }}$ to $6^{\text {th }}$ weeks of age. The highest mean body weight gain was observed in T5 ( $2.0 \mathrm{~g} / \mathrm{kg}$ NLP) group which is statistically compared with T4 (1.0g/kg NLP). While T1 (control) group recorded lowest mean weight gain and statistically comparable with T3 (1.0 g/kg GP). There was no significant $(\mathrm{p}<0.05)$ difference in weight gain between treatment T7 (1.0 g/kg GP+2.0 g/kg NLP) and
T2 (0.5 g/kg GP). Among GP supplemented groups, $0.5 \mathrm{~g} / \mathrm{kg}$ GP (T3) gained more weight compared to $1.0 \mathrm{~g} / \mathrm{kg}$ GP (T4) group. The supplementation of $0.5 \mathrm{~g} /$ $\mathrm{kg}$ GP+1.0 g/kg NLP $\left(\mathrm{T}_{6}\right)$ showed improved body weight gains in comparison to T7 (1.0 g/kg GP+2.0 g/ kg NLP) (Table-1).

\section{FCR (Feed intake/ body weight gain)}

Significant $(p<0.05)$ difference were revealed for FCR in all the treatments from $1^{\text {st }}$ to $6^{\text {th }}$ weeks of age. Poor FCR was observed in T1 and better FCR was observed in group T7. The results indicate that birds fed with higher doses of GP $(1.0 \mathrm{~g} / \mathrm{kg})$ and NLP $(2.0 \mathrm{~g} / \mathrm{kg})$ and their combinations $(1.0 \mathrm{~g} / \mathrm{kg}+2.0 \mathrm{~g} / \mathrm{kg})$ showed better FCR (Table-2).

\section{Carcass yield}

Dietary supplementation of GP and NLP alone and their combination did not significantly $(\mathrm{p}<0.05)$ influenced the dressing yield and giblet yield (liver, heart and gizzard) in broilers (Table-3).

\section{Discussion}

In the present study, supplementation of GP and NLP alone and their combination significantly $(\mathrm{p}<0.05)$ improved the body weight gain. Similar findings with respect to improvement in body weight gain was observed by earlier researchers [9-11]. The improvement in weight gain might be due to anti-protozoal and immunostimulatory properties of neem leaves that help to reduce the microbial load and improved the performance [12]. In the contrary to our findings, there is also some reports in which birds exhibited poor performance and lower body weights in all treatment groups [13]. While some earlier reports showed no significant variations in weight gain of broilers [14-16].

Among GP supplemented groups, $0.5 \mathrm{~g} / \mathrm{kg}$ GP (T3) gained more weight compared to $1.0 \mathrm{~g} / \mathrm{kg}$ GP (T4) group. The reduction in body weight gain at higher doses might be due to increasing in repulsive odour and taste of garlic [17]. Improvement in weight gain $0.5 \mathrm{~g} / \mathrm{kg}$ might be due the fact that allicin (an antibiotic substance found in garlic), inhibits growth of intestinal bacteria and inhibit aflatoxins producing fungi resulting in lowering the load of these organisms

Table-1: Effect of supplementing garlic and NLPs and their combinations on weight gain of broilers.

\begin{tabular}{|c|c|c|c|c|c|c|c|c|}
\hline \multirow[t]{2}{*}{ Treatments } & \multicolumn{7}{|c|}{ Weeks } & \multirow{2}{*}{$\begin{array}{c}\text { Cumulative } \\
\text { gain }\end{array}$} \\
\hline & Day old & 1 & 2 & 3 & 4 & 5 & 6 & \\
\hline T1 & 47.23 & $80.00^{\mathrm{e}}$ & $174.67^{e}$ & $283.17^{d}$ & $384.22^{\mathrm{e}}$ & $425.33^{d}$ & $371.00^{d}$ & $1718.38^{d}$ \\
\hline T2 & 47.23 & $83.33^{\text {cde }}$ & $179.00^{\text {de }}$ & $290.00^{c}$ & $387.18^{\text {cde }}$ & $455.00^{c}$ & $385.00^{c}$ & $1779.52^{c}$ \\
\hline T3 & 47.43 & $82.00^{\mathrm{de}}$ & $177.00^{\text {de }}$ & $288.00^{c}$ & $385.17^{\text {de }}$ & $429.17^{d}$ & $375.17^{d}$ & $1736.50^{d}$ \\
\hline T4 & 47.50 & $89.00^{\mathrm{ab}}$ & $187.00^{\mathrm{ab}}$ & $298.00^{a b}$ & $394.00^{\mathrm{ab}}$ & $478.22^{a}$ & $401.22^{\mathrm{a}}$ & $1847.43^{a}$ \\
\hline T5 & 47.37 & $91.00^{a}$ & $191.00^{a}$ & $300.00^{a}$ & $396.00^{a}$ & $482.00^{a}$ & $403.17^{a}$ & $1863.17^{a}$ \\
\hline T6 & 47.67 & $87.00^{\mathrm{abc}}$ & $185.00^{\mathrm{bc}}$ & $295.17^{b}$ & $391.20^{b c}$ & $461.17^{b}$ & $395.00^{\mathrm{b}}$ & $1814.53^{b}$ \\
\hline T7 & 47.64 & $85.00^{\mathrm{bcd}}$ & $181.33^{\mathrm{cd}}$ & $289.17^{c}$ & $389.17^{c d}$ & $456.17^{c}$ & $387.00^{c}$ & $1787.83^{c}$ \\
\hline SEM & 0.16 & 0.77 & 0.98 & 1.01 & 0.83 & 3.19 & 1.86 & 8.35 \\
\hline p-value & $0.98^{\mathrm{NS}}$ & 0.00 & 0.00 & 0.00 & 0.00 & 0.00 & 0.00 & 0.00 \\
\hline
\end{tabular}

Values bearing different superscripts within a column are significantly $(p<0.05)$ different. SEM=Standard error of the mean, NS=Non-significant, NLP=Neem leaf powder 
Table-2: Effect of supplementing garlic and NLPs in experimental diets on FCR of broiler chicken.

\begin{tabular}{|c|c|c|c|c|c|c|c|}
\hline \multirow[t]{2}{*}{ Treatments } & \multicolumn{6}{|c|}{ Weeks } & \multirow{2}{*}{$\begin{array}{c}\text { Cumulative } \\
\text { FCR }\end{array}$} \\
\hline & 1 & 2 & 3 & 4 & 5 & 6 & \\
\hline $\mathrm{T1}$ & $1.41^{\mathrm{c}}$ & $1.61^{\mathrm{e}}$ & $1.65^{d}$ & $1.84^{d}$ & $1.91^{\mathrm{g}}$ & $2.05^{e}$ & $1.83^{e}$ \\
\hline $\mathrm{T} 2$ & $1.39^{c}$ & $1.58^{\mathrm{d}}$ & $1.63^{c}$ & $1.84^{d}$ & $1.80^{\mathrm{e}}$ & $1.98^{\mathrm{d}}$ & $1.78^{d}$ \\
\hline T3 & $1.32^{\mathrm{b}}$ & $1.52^{\mathrm{b}}$ & $1.57^{\mathrm{a}}$ & $1.80^{\mathrm{b}}$ & $1.83^{f}$ & $1.97^{c}$ & $1.75^{\mathrm{c}}$ \\
\hline T4 & $1.32^{\mathrm{b}}$ & $1.55^{c}$ & $1.63^{c}$ & $1.83^{d}$ & $1.73^{\mathrm{bc}}$ & $1.97^{c}$ & $1.75^{c}$ \\
\hline T5 & $1.27^{\mathrm{a}}$ & $1.49^{a}$ & $1.59^{\mathrm{b}}$ & $1.81^{\mathrm{c}}$ & $1.71^{\mathrm{a}}$ & $1.94^{\mathrm{b}}$ & $1.72^{\mathrm{b}}$ \\
\hline T6 & $1.28^{\mathrm{a}}$ & $1.52^{\mathrm{b}}$ & $1.59^{b}$ & $1.82^{\mathrm{c}}$ & $1.75^{d}$ & $1.91^{\mathrm{a}}$ & $1.73^{\mathrm{b}}$ \\
\hline T7 & $1.27^{a}$ & $1.48^{a}$ & $1.56^{\mathrm{a}}$ & $1.78^{a}$ & $1.72^{\mathrm{ab}}$ & $1.91^{\mathrm{a}}$ & $1.70^{\mathrm{a}}$ \\
\hline SEM & 0.01 & 0.01 & 0.02 & 0.02 & 0.01 & 0.02 & 0.01 \\
\hline$p$-value & 0.00 & 0.00 & 0.00 & 0.00 & 0.00 & 0.00 & 0.00 \\
\hline
\end{tabular}

Values bearing different superscripts within a column are significantly $(\mathrm{p}<0.05)$ different, $\mathrm{SEM}=\mathrm{Standard}$ error of the mean, $\mathrm{FCR}=$ Feed conversion ratio, NLP $=$ Neem leaf powder

Table-3: Effect of supplementing garlic and NLPs and their combinations on carcass yields of broiler at 42 day of age.

\begin{tabular}{lcccc}
\hline Treatments & \multicolumn{4}{c}{ Carcass parameters (\%) } \\
\cline { 2 - 5 } & $\begin{array}{c}\text { Dressing } \\
\text { yield }\end{array}$ & $\begin{array}{c}\text { Heart } \\
\text { weight }\end{array}$ & $\begin{array}{c}\text { Gizzard } \\
\text { weight }\end{array}$ & $\begin{array}{c}\text { Liver } \\
\text { weight }\end{array}$ \\
\hline T1 & 71.60 & 0.43 & 1.82 & 2.31 \\
T2 & 70.75 & 0.52 & 2.09 & 1.97 \\
T3 & 71.44 & 0.35 & 2.00 & 2.04 \\
T4 & 71.27 & 0.40 & 1.91 & 2.15 \\
T5 & 71.12 & 0.47 & 2.03 & 2.39 \\
T6 & 70.60 & 0.36 & 1.72 & 2.21 \\
T7 & 71.66 & 0.41 & 1.93 & 2.22 \\
SEM & $1.57^{N S}$ & $0.01^{\text {NS }}$ & $0.04^{\text {NS }}$ & $0.13^{N S}$ \\
p-value & 0.712 & 0.066 & 0.165 & 0.439 \\
\hline
\end{tabular}

$\mathrm{NS}=$ Non-significant, $\mathrm{SEM}=$ Standard error of the mean, $\mathrm{NLP}=$ Neem leaf powder

in the intestine and birds may absorb more nutrients leading to the improvement in weight gain of the birds using rations supplemented with garlic. These findings were in agreement with $[17,18]$.

The supplementation of combination of $0.5 \mathrm{~g} / \mathrm{kg} \mathrm{GP}+1.0 \mathrm{~g} / \mathrm{kg}$ NLP $\left(\mathrm{T}_{6}\right)$ showed improved body weight gains in comparison to $\mathrm{T} 7(1.0 \mathrm{~g} / \mathrm{kg}$ $\mathrm{GP}+2.0 \mathrm{~g} / \mathrm{kg} \mathrm{NLP})$. In an experiment, supplementation of diet with $1 \%$ neem leaf meal and pawpaw leaf meal improved performance, as neem leaf might have suppressed the growth of harmful organisms, thereby creating a conducive environment for the active substances in the pawpaw leaf to aid digestion and give better performance [11]. Similar mechanism of action would have occurred while supplementing GP and NLP in combination at lower dose.

In the present study, supplementation of GP and NLP alone and their combination significantly $(p<0.05)$ improved the FCR. The higher body weight gains might be due to growth promoting and antimicrobial property of garlic and neem leaves that helped to reduce the microbial load of birds and improved feed efficiency $[12,19]$. Similar findings with respect to increased FCR were reported by earlier researchers $[9,10,12,18,20,21]$. In contrary to findings of this study, some authors observed that the supplementation of garlic and neem leaves had no significant ( $>>0.05$ ) effect FCR [14,16,22-26].

In the present study, there was no significant ( $>0.05$ ) influence on carcass parameters like dressing yield and giblet yield (heart, gizzard and liver) in all dietary groups. These results are in agreement with earlier researchers [15,17,23,25,27-30]. In the contrary with these findings, a significant increase in average dressing percentage with supplementation of garlic [18] and neem $[9,11]$ was also reported by earlier workers in broilers.

\section{Conclusion}

Supplementation of GP and NLP alone or in combination significantly $(\mathrm{p}<0.05)$ influenced the growth performance of broilers in comparison to control. Supplementation of $1.0 \mathrm{~g} / \mathrm{kg} \mathrm{GP}+2.0 \mathrm{~g} / \mathrm{kg}$ NLP proved most efficient as it showed best FCR. Carcass yield was not affected by feeding of GP and NLP in all the treatment groups. Thus combine supplementation of GP and NLP can be used as feed additives in broilers for improving the performance.

\section{Authors' Contributions}

KRK planned, designed the study and analysed the data. SS assisted in literature collection. Manuscript was drafted and revised by SS under the guidance of KRK. Both authors read and approved the final manuscript.

\section{Acknowledgments}

The research grant was provided by Sri Venkateshwara Veterinary University, Tirupati in the farm of stypand. The authors are thankful to Dean, College of Veterinary Science, S.V.V.U, Tirupati for providing facilities and funds for the research.

\section{Competing I nterests} interests.

The authors declare that they have no competing

\section{References}

1. Newall, C.A., Anderson, L.A., and Phillipson, J.D. (1996) Herbal Medicines: A Guide for Health-Care Professionals. Vol. IX. Pharmaceutical Press, London, p296.

2. Chowdhury, S.R., Chowdhury, S.D., and Smith, T.K. (2002) 
Effects of dietary garlic on cholesterol metabolism in laying hens. Poult. Sci., 81(12): 1856-1862.

3. Sumiyoshi, H. (1997) New pharmacological activity of garlic and its constituent (review). Folia. Pharmacol. Jpn., 110(1): 93-97.

4. Bradley, P.R. (1992) British Herbal Compendium: A Handbook of Scientific Information on Widely Used Plant Drugs. British Herbal Medicine Association and Produced by its Scientific Committee, Bournemouth, Dorset: The Association.

5. Biswas, K., Chattopadhyay, I., Banarjee, R.K. and Bandyopadhyay, U. (2002) Biological activities and medicinal properties of neem (Azadirachta indica). Curr. Sci. Rev., 82(11): 1336-1345.

6. Subapriya, R. and Nagini, S. (2005) Medicinal properties of neem leaves. Curr. Med. Chem. Rev., 5(2): 149-156.

7. Padalwar, R.V. (1994) Neem (Azadirachta indica) leaves as feed supplement in broiler ration. Unpublished M.V.Sc Thesis Submitted to Dr. Punjabrao Deshmukh Krishi Vidyapeth, Akola.

8. Duncan, D.B. (1955) Multiple range and multiple $F$ tests. Biometrics., 11: 1-42.

9. Zanu, H.K., Kagya-Agyemang, J.K., Kwenin, W.K.J., Bonsu, F.R.K., Antwi, E., and Ateni, S. (2011) Physiological response of broiler chickens to neem and akakapenpen decoctions: Performance and carcass characteristics. Int. J. Poult. Sci., 10(9): 730-733.

10. Ansari, J., Khan, S.H., ul Haq, A. and Yousaf, M. (2012) Effect of the levels of Azadirachta indica dried leaf meal as phytogenic feed additive on the growth performance and haemato-biochemical parameters in broiler chicks. J. Appl. Anim. Res., 40(4): 336-345.

11. Adeyemo, G.O. and Akanmu, A.M. (2013) Effects of neem (Azadirachta indica) and Pawpaw (Carica papaya) leaves supplementation on performance and carcass characteristics of broilers. Available from: http://wwwen.engormix.com/ MA-poultry industry/nutrition/articles. Last accessed on 08-12-2013.

12. Wankar, A.K., Shirbhate, R.N., Bahiram, K.B., Dhenge, S.A. and Jasutkar, R.A. (2009) Effect of neem leaf powder supplementation on growth in broilers. Vet. World., 2(10): 396-397.

13. Deore, U.B., Ingole, R.S., Waghmare, S.P., Pathak, V.P. and Joshi, M.V. (2005) Clinicopathological investigations in broilers given different levels of neem oil supplementation in feed. J. Bombay Vet. Coll., 13(1-2): 110-111.

14. Nidaullah, H., Durrani, F.R., Ahmad, S., Jan, I.U. and Gul, S. (2010) Aqueous extract from different medicinal plants as anticoccidial, growth promotive and immunostimulant in broilers. J. Agric. Biol. Sci., 5(1): 53-59.

15. Bonsu, R.K., Kagya-Agyemang, J.K., Kwenin, W.K.J. and Zanu, H.K. (2012) Medicinal response of broiler chickens to diets containing neem (Azadirachta indica) leaf meal, haematology and meat sensory analysis. World Appl. Sci. J. 19(6): 800-805.

16. Nnenna, O.P. and Okey, A.A. (2013) Toxicity and nutritional assessment of aqueous Azadirachta indica (neem) leaf extract in broiler chicks. Int. J. Biosci., 3(6): 172-180

17. Pourali, M., Mirghelenj, S.A. and Kermanshahi, H. (2010) Effects of garlic powder on productive performance and immune response of broiler chickens challenged with Newcastle disease virus. Glob. Vet., 4(6): 616-621.

18. Fayed, R.H., Razek, A.H.A. and Jehan, M.O. (2011) Effect of dietary garlic supplementation on performance, carcass traits and meat quality in broiler chickens. Animal Hygiene and Sustainable Livestock Production. Vol. 1. Proceedings of the $\mathrm{XV}^{\text {th }}$ International Congress of the International Society for Animal Hygiene, Vienna, Austria. p471-474.

19. Sun Jong, Y., Byoung Ki, A. and Chang Won, K. (2009) Effects of dietary garlic powder on growth performance and mRNA expression of hepatic HMG-CoA reductase in broiler chickens. J. Anim. Sci. Technol., 51(4): 307-314.

20. Fadlalla, I.M.T., Mohammed, B.H. and Bakhiet, A.O. (2010) Effect of feeding Garlic on performance and immunity of broilers. Asian J. Poult. Sci., 4(4): 182-189.

21. Suliman, A.J.C., Subah, A.M. and Dallah, S.A. (2011) Using garlic paste as feed additive in high nutrients density broiler diets on performance and biochemical parameters. Assiut. Vet. Med. J., 57(35): 129, 302-322.

22. Choi, I.H., Park, W.Y. and Kim, Y.J. (2010) Effects of dietary garlic powder and alpha -tocopherol supplementation on performance, serum cholesterol levels and meat quality of chicken. Poult. Sci., 89(80): 1724-1731.

23. Kirkpinar, F., Bora Unlu H. and Ozdemir, G. (2010) Effects of oregano and garlic essential oils on performance, carcass, organ and blood characteristics and intestinal microflora of broilers. Livest. Sci., 137(1): 219-225.

24. Ao, X., Yoo, J.S., Zhou, T.X., Wang, J.P., Meng, Q.W., Yan, L., Cho, J.H. and Kim, I.H. (2011) Effects of fermented garlic powder supplementation on growth performance, blood profiles and breast meat quality in broilers. Livest. Sci., 141(1): 85-89.

25. Amouzmehr, A., Dastar, B., Nejad, J.G., Kyung, S., Lohakare, J. and Forghani, F. (2012) Effects of garlic and thyme extracts on growth performance and carcass characteristics of broiler chicks. J. Anim. Sci. Technol., 54(3): 185-190.

26. Issa, K.J. and Abo Omar, J.M. (2012) Effect of garlic powder on performance and lipid profile of broilers. Open $J$. Anim. Sci., 2(2): 62-68.

27. Dono, N.D. (2010) Meat quality of broiler fed diet supplemented by garlic meal and white turmeric meal. J. Ilmu. Ternak dan Vet., 15(2): 81-87.

28. Abdullah, A.Y., Mahmoud, K.Z., Nusairat, B.M., and Qudsieh, R.I. (2010) Small intestinal histology, production parameters, and meat quality as influenced by dietary supplementation of garlic (Allium sativum) in broiler chicks. Ital. J. Anim. Sci., 9: e80.

29. Toghyani, M., Gheisari, A., Ghalamkari, G. and Eghbalsaied, S. (2011) Evaluation of cinnamon and garlic as antibiotic growth promoter substitutions on performance, immune responses, serum biochemical and haematological parameters in broiler chicks. Livest. Sci., 138(1/3): 167-173.

30. Landy, N., Ghalamkari, G.H. and Toghyani, M. (2011) Performance, carcass characteristics, and immunity in broiler chickens fed dietary neem as alternative for an antibiotic growth promoter. International Conference on Life Science and Technology, IPCBEE. Vol. 3. 